\title{
IAMJ
}

INTERNATIONAL

AYURVEDIC

MEDICAL JOURNAL

Review Article

ISSN: 2320-5091

Impact Factor: 6.719

\section{SPORT INJURIES AND ITS MANAGEMENT THROUGH AYURVEDA}

$\underline{\text { Sonia Meend }}^{1}$, $\underline{\text { Sunil Kumar }}^{2}$

MD Scholar, Dept. of Sharir Rachana, National Institute of Ayurveda, Jaipur, Rajasthan, India

Prof. and Head of Department, Dept. of Sharir Rachana, National Institute of Ayurveda, Jaipur, Rajasthan, India

Corresponding Author: soniya17you@gmail.com

https://doi.org/10.46607/iamj2909052021

(Published Online: May 2021)

Open Access

(C) International Ayurvedic Medical Journal, India 2021

Article Received: 30/04/2021 - Peer Reviewed: 05/05/2021 - Accepted for Publication: 07/05/2021

Check for updates

\section{ABSTRACT}

A sport injury is a type of injury which can be defined as any kind of injury, pain or physical damage that occurs during sports, exercise, or any physical activity. Sports medicine helps people in improving their performance in sports, fast recovery from injury and prevent future injuries. Ayurveda being the oldest science to serve mankind can prove to be the best science in management of the sport injuries. Various methods mentioned in Ayurveda classics like Vyayama (physical exercise), Abhyanga (an-ointment), Rasayana (rejuvenation) Therapy, Marma (vital points) Therapy, yogic practices, Pranayamas (meditation technique) etc. proves to be a boon for a sports person for his performance as well as to overcome the physical and mental trauma suffered during the sport.

Keywords: sport injury, sport medicine, Vyayama, Marma

\section{INTRODUCTION}

A sport injury is a type of injury which can be defined as any kind of injury, pain or physical damage that occurs during sports, exercise, or any physical activity. It is most commonly the musculoskeletal injuries which include muscle, bones, cartilage and associated tissue. Sports injuries can be caused by an accident, impact, poor training practices, improper equipment, lack of conditioning, insufficient warm up and stretching.

Sports medicine helps people improve their athletic performance, recover from injury and prevent future injuries. Ayurveda in the field of sports medicine is a fastgrowing, because Ayurveda health workers who 
specialize in sports medicine help all kinds of people, not just athletes.

\section{COMMON CLINICAL CONDITIONS RELATED TO SPORT INJURIES IN AYURVEDA}

Ayurveda being the oldest science to nurture human life, has mentioned many sport injuries, not directly by this name but we find a lot of scattered references in Samhitas(ancient ayurvedic classics) which gives complete information and treatment as well of the mentioned injuries.

Acharya Madhava in Madhava Nidaana, has mentioned a list of sport injuries under one roof of chapter "Vaat Vyadhi Nidaanam". Acharya also stated Abhighata (traumatic injury) as one of the Nidaanas (causative factor) of Vata vyadhi (disorders due to Vata dosha). Acharya Charaka also stated a number of Vata vyadhis (disorders due to vitiated Vata dosha) which on the Lakshanas (prodromal features) can be compared to present day Sport injuries. 1

Diseases which can be correlated with modern day sport injuries are

1. Mamsa, Meda Gata Vata (vitiated vata in Mamsa and Meda) - bruises, sprains and strains caused while getting injured during sports.

2. Snayu Gata Vata (vitiated vata in Snayu) - soft tissue injuries

3. Trika Gata Vata (vitiated vata in the Trika region) - low back pain

4. Gridhrasi-sciatic pain

5. Kroshtukashirsha - torn anterior and medial cruciate ligament

6. Khalli-muscle or tendon pulling during exercise training.

7. Vishwachi-median nerve injury occurred during extensive sport training.

8. Pada daha - plantar fasciitis

9. Bhagna - fractures

10. Sandhimokshana-dislocations

11. Vrana (injuries) - open wounds

12. Vranashopha (swellings) - inflammatory swellings

\section{MANAGEMENT OF SPORT INJURIES}

Sport medicine is a branch of medical science which deals with the prevention of sport related injuries. Sport medicines include specialties of cardiology, mycology, orthopedics, surgery, physiotherapy, biomechanics etc. Ayurveda science being the living science focuses on preventing the disease by giving measures for maintenance of health of the individuals as well the treatment of the diseases.

Many principles of Ayurveda can be used by sportsmen to prevent injury during the playing sports. Ayurveda emphasizes on Dincharya (the proper daily healthy regimes) and Ritucharya (seasonal regimes) to be followed, the food habits and the living habits to be adopted according to a particular season to obtain optimum level of health in any individual.

\section{Vyayama}

For a person who is indulged in sport activities, physical fitness plays a very important role. Acharya Charaka defines Vyayama as physical activities which is desirable and capable of bringing body stability and increase strength of body when done in proper measure. Ayurveda also states about how one should carry on the exercise routine according to seasonal changes as in Hemanta Ritu (pre-winter season) and Shishira Ritu (winter season), Bala (strength) of an individual is highest and so he can perform even heavy exercises while on the other hand, Bala (strength) of the individual is less in Grishma Ritu (summer season) so one should not do exercise in this ritu. 2

\section{Abhyanga}

Abhyanga means application of oil and massaging the body. Often medicated and usually warm oil is used to massage over the entire body. It is beneficial for maintenance of health and used as a medicine for various disorders. It can be used as a routine for almost everyone. Abhyanga therapy is an ancient practice of Vedic period.

Application of oil to the skin and massaging in a specific direction is well known by the term Abhyanga in Ayurveda. Massage in a specific direction improves blood circulation, helps in removal of the toxins from the tissues, relieves physical and mental fatigue, improves the functioning of musculoskeletal system, clears stiffness and heaviness of the body and leads to feeling of lightness. It assists development of healthy body, recuperates the body tissues and reduces body 
weight as well as fat. In addition to this, Abhyanga has curative effect on plethora of diseases by the pharmacological action of the drugs used in the processing of the oil.

\section{Use of Rasayana therapy}

Rasayana is one of the eight major clinical disciples of Ayurveda. Rasayana therapy should be included in training period and also in routine life of a sports person. Rasayana nourishes all the Dhatus (tissues) of body, increase stamina by increasing Bala of body, increase Dhatu Sara (tissue excellence) and Oja (essence of all Dhatus) and thereby provides immunity to various disease and increase quality of life. It increases memory power, health, lusture, complexion etc. soothenes the brain and therefore strengthen the sensory and motor reflexes of body.

\section{Vata Vyadhi}

In a person who is engaged in heavy exercises, there is more chances of Vata Dosha to get aggravated. Aggravated Vata Dosha can cause a majority of diseases. To treat this, there are different treatment protocols mentioned in Ayurveda. For eg - in Bahu Shirshagatavata (Vata vitiated in arms and head), procedure of Nasya is advised by different Vatashamaka Oils (medicated oils curbing Vata dosha) and usage of medicated Ghritam after meal.3

Similarly, to conquer the aggravated Vata in Asthi (bones) and Majja (bone marrow), usage of Vatashamaka oils and Ghritam are advised for internal and external application.4

In Snayu Gata Vata, Agnikarma (Thermal Microcautery) is advised on the site of injury.

Acharya Sushruta stated intake of milk cooked with Panchamoola Kwath (decoction made of Panchamoola drugs), Dhanya Yoosha (soup of cereals) are wholesome food for Vaat Vyadhi. Usage of Tilvak Ghritam, Anu Tailam for Nasya, Shatpaaka Tailam, various Lavana preparation like Patra Lavana, Sneha Lavana, Kalyanaka Lavana etc. are also indicated. 5

\section{Vrana and Vranashopha}

Most of persons who are engaged in different sports suffers from various types of wounds/injury. Acharya Sushruta have given sixty type of treatment protocols for various types of Vranas (wounds) and
Vranashophas (inflammatory swellings). Moreover, Acharya also mentioned treatment of Sadyo Vrana (fresh wounds) which are most common injury to a sport person during the physical activity. Sixty measures include Apatarpana (de-saturation), Alepana (application of paste), Parisheka (sprinkling), $A b$ hyanga (anointment), Swedana (fomentation), Vimlapana (gentle pressure), Upnaha (poultice), Pachana (ripening), Visravana (bloodletting), Bandha (bandaging), etc. 6 Apatarpana (desaturation) is the first therapeutic method and is applied in all forms of inflammatory swellings. Abhyanga and Swedana (fomentation) should be applied in early stages and if the swelling is painful then Visravana (bloodletting) is performed 7. Furthermore, use of Matulungadi, Doorvadi, Ajagandhadi gana drugs is advised in Vataja, Pittaja and Kaphaja swelling respectively8. Intake of Shodhana Sarpi is also advised.9

Moreover, it is stated that wounds which are situated on movable joints and which are unmanageable should be managed with Raskriya containing Haridra (Curcuma longa) and Daruharidra (Berberis aristata) 10. For the wounds that are Udhrdhva Jatru Gata (located in supraclavicular region) provision of Nasya is mentioned.11

Drugs like Tryodashanga Tailam, medicated oils prepared from drugs like Samanga (Rubia cordifolia), Rajni (Curcuma longa), Vidanga (Embelica ribes), Guduchi (Tinospora cordifolia) etc. is proven excellent in wound healing. 12

\section{Treatment of Bhagna and Sandhimokshana (frac- tures and dislocation)}

Acharya Sushruta have given systematic different methods of Bhagna Sandhana (management of fractures). in the first step, Acharya Sushruta has stated techniques of closed reduction especially by the application of various forces like Aanchhana (traction), Peedana (compression), Sankshepana (reduction or compression), Unmanna (pulling upwards), Vinmanna (pressing downwards) etc. After the injury has been fixed in position or reduced, movement of the fractured parts has to be restricted till it unite. For this purpose, two methods have been mentioned by Acharyas viz. Kusha Bandhana (Splintage or external 
immobilization) and Kapaata Shayana (fracture bed). Principles of physiotherapy have also been mentioned by Acharya Sushruta in the name as Sukhchestaprasara (physiotherapy). It is important to bring back the normal functions of the affected parts as soon as possible, mainly by giving the strength to bones and soft tissues. In Sushruta Samhita for the management of fractures of bones of palm (meta-carpals), gradually increasing weight bearing has been described. It has been mentioned that the patient should hold Mritpinda (ball of clay) then Lavana (salt) and finally Pashana (a piece of stone) in his palm to regain the strength 13

\section{Marma therapy and sport medicine}

Marma are vital points in the body. In Ayurveda science, Marma points are specific anatomical locations in the body in which concentrated of life energy exists. Marma therapy is a recent practice of stimulating these spots through gentle massage therapy. It can be both relaxing and invigorating. It not only helps loosen your muscle and tissue, but it also helps to promote proper flow of energy around your body.

\section{Yoga and Meditation}

For a person to perform well in games, peaceful mind along with physical fitness is very important. For this yoga and meditation plays a significant role.

Yoga is defined as "Chhittavrutti Nirodha" by Acharya Patanjali which means that fluctuation of mind can be reversed by yogic practices and meditation. Yogasanas should not only be treated as physical exercise routine but a scientific rhythmic training for physical, mental and spiritual self. The practice of asanas also improves endurance and tonicity of muscles. For e.g. Asana like Veer Bhadrasana, Ardha Chandrasana, Sarvangasana, etc. helps in strengthening leg muscles, tones abdominal muscles, and also improves body balance. Also, Pranayama techniques improves concentration, helps in maintaining blood pressure. All these practices help a sportsman to give his best during the play.

\section{DISCUSSION}

As Ayurveda always work on the principle of "Swasthasya Swasthya Rakshanam Aturasaya Vikara Prashmanam Cha”, so in order to achieve optimum health status in sportsmen, Ayurvedic principles and medicines can be successfully incorporated in all fields of sports, beginning from training upto treatment of injuries on and off the field. The curriculum of sports training period of a sportsman can be effectively reformed by adding Ayurveda principles of Dincharya and Ritucharya for improving overall health status and performance. Moreover, for a good mental health and concentration, Yoga and Pranayama techniques should be incorporated in daily habitude of a sports person. Inclusion of Rasayana therapy helps in building the required stamina for the sports person and also strengthen the sensory and motor reflexes of body.

For the treatment aspect, Ayurveda has surplus of drugs and practices. Vata vyadhis mentioned by our Acharyas can be correlated with modern day sports injuries and their treatment explained in classical texts can be successfully used in management of sports injuries. For various types of Vranas and Vranashopha which are common sport injuries, sixty types of therapeutic measures along with plethora of drugs and combinations are given by Acharya Sushruta. Furthermore, for successful management of Bhagna and Sandhimokshana which are most frequently occurring sport injuries, systematic methods of management are given in our ancient texts along with post traumatic exercises which could be compared to modern day physiotherapy. Also, inclusion of Marma therapy could prove to be a boon in the field of sports medicine as it leads to successful results in less time and is also a painless technique.

The incorporation of the successful methods and medicines of alternative medicine can help a sports person to improve his performance and also minimize the heavy usage of modern medicine.

\section{CONCLUSION}

Therefore, we can say that Ayurveda ancient classics have mentioned about the sport injuries; not directly by the name but under the heading of "Vata Vyadhis". And Various methods mentioned in Ayurveda classics like Vyayama, Abhyanga, Rasayana therapy, Marma therapy, yogic practices, Pranayamas etc. proves to be a boon for a sports person for his performance as well 
as to overcome the physical and mental trauma suffered during the sport.

\section{REFERENCES}

1. PV Sharma / Caraka Samhita (text with English translation) / Volume II, Chikitsa sthana chapter 28 (vata vyadhi chikitsa), verse 25-58 / Chaukhambha Orientalia /Varanasi/ 1998 / Reprint Edition 4/ pg no. 463-467

2. PV Sharma / Caraka Samhita (text with English translation) / Volume I, Sutrasthana chapter 6(tasyashritiya), verse 39 / Chaukhambha Orientalia /Varanasi/ 1998 / Reprint Edition 4/ pg no.90

3. PV Sharma / Caraka Samhita (text with English translation) / Volume II, Chikitsa sthana chapter 28 (vata vyadhi chikitsa), verse 98 / Chaukhambha Orientalia /Varanasi/ 1998 / Reprint Edition 4/ pg no. 470

4. PV Sharma / Caraka Samhita (text with English translation) / Volume II, Chikitsa sthana chapter 28 (vata vyadhi chikitsa), verse 93 / Chaukhambha Orientalia /Varanasi/ 1998 / Reprint Edition 4/pg no. 470

5. Ambikadatta Shastri / Sushruta Samhita with Ayurvedatatva sandeepika Hindi commentary/ Sushruta Samhita Chikitsa Sthana, Chapter 2 (sadyovraniya), verse 84 / Chaukhamba Sanskrit Sansthan/ Varanasi/2014/ Reprint 2nd edition/ pg no.25

6. Ambikadatta Shastri/ Sushruta Samhita Ayurvedatatvasandeepika Hindi commentary/Sushruta Samhita Chikitsa Sthana, Chapter 1 (dwivraniya) verse 8/ Chaukhamba Sanskrit Sansthan /Varanasi/ 2014/ Reprint 2nd edition/pg no. 5

7. Ambikadatta Shastri/ Sushruta Samhita Ayurvedatatvasandeepika Hindi commentary/ Sushruta Samhita Chikitsa Sthana, Chapter 1 (dwivraniya) verse 20; Chaukhamba Sanskrit Sansthan /Varanasi/ 2014/ Reprint 2nd edition/pg no 7

8. Ambikadatta Shastri/ Sushruta Samhita Ayurvedatatvasandeepika Hindi commentary/ Sushruta Samhita, Chikitsa Sthana, Chapter 1 (dwivraniya) verse 17/ Chaukhamba Sanskrit Sansthan/ Varanasi/ 2014/ Reprint 2nd edition/ Pg no 6

9. Ambikadatta Shastri/Sushruta Samhita Ayurvedatatvasandeepika Hindi commentary/Sushruta Samhita, Chikitsa Sthana, Chapter 1(dwivraniya) verse 5657/ Chaukhamba Sanskrit Sansthan/ Varanasi/ 2014/ Reprint 2nd edition/ Pg no. 10

10. Ambikadatta Shastri/ Sushruta Samhita Ayurvedatatvasandeepika Hindi commentary/ Sushruta Samhita, ChikitsaSthana, Chapter 1(dwivarniya) verse 5861/ Chaukhamba Sanskrit Sansthan/ Varanasi/ 2014/ Reprint 2nd edition/ Pg no. 10

11. Ambikadatta Shastri/ Sushruta Samhita Ayurvedatatvasandeepika Hindi commentary/ Sushruta Samhita, Chikitsa Sthana, Chapter 1(dwivarniya) verse 126 / Chaukhamba Sanskrit Sansthan/ Varanasi/ 2014/ Reprint 2nd edition/Pg no. 16
12. Ambikadatta Shastri/ Sushruta Samhita Ayurvedatatvasandeepika Hindi commentary/ Sushruta Samhita, Chikitsa Sthana, Chapter 2(sadyovarniya) verse 40 / Chaukhamba Sanskrit Sansthan/ Varanasi/ 2014/ Reprint 2nd edition/Pg no. 21

13. Ambikadatta Shastri/ Sushruta Samhita Ayurvedatatvasandeepika Hindi commentary/ Sushruta Samhita, Chikitsa Sthana, Chapter 3 (bhagna chikitsa) verse 55-63 / Chaukhamba Sanskrit Sansthan/ Varanasi/ 2014/ Reprint 2nd edition /Pg no.30a

\section{Source of Support: Nil \\ Conflict of Interest: None Declared}

How to cite this URL: Sonia Meend \& Sunil Kumar: Sport Injuries And Its Management Through Ayurveda. International Ayurvedic Medical Journal \{online\} 2021 \{cited May, 2021\} Available from: http://www.iamj.in/posts/images/upload/1116 1120.pdf 